\title{
Innovation Processes and Technologies for Improvement and Support of Education
}

\author{
Peter Balco \\ Comenius University, Faculty of Management, Department of Information \\ Systems, Bratislava, Slovakia \\ Martina Drahošová \\ Slovak Innovation and Energy Agency, Bratislava, Slovakia \\ Michal Greguš, Jr. \\ Comenius University, Faculty of Management, Department of Information \\ Systems, Bratislava, Slovakia
}

\begin{abstract}
The education institutions present a complicated economic and social ecosystem with many processes that are constantly under pressure from many stakeholders. Learning organizations are trying to find ways to improve them, but they crash at "unmistakable claims" about the need to build extensive infrastructure for modernization, innovation and greater efficiency. This approach creates requirements for the maintenance and operation of complicated technologies that naturally requires additional resources, both financial and human. In our contribution, we want to present innovative approaches in processes of education based on the agile event management. The agile environment enforces to use the intelligent tools through providers, third parties, allowing automation of service management and replacing many manual activities. Automation provides two-way real-time communication that creates space for users quickly respond to different needs, events and increase productivity.
\end{abstract}

Keywords: education, automation, artificial intelligent, universities JEL classification: M21

\section{Introduction}

Innovation is an important output of organizations interested in keeping on the market and securing their long-term economic growth. From a definition point of view, they are defined as a specific tool of entrepreneurs, a means by which they use changes as opportunities to differentiate their business or services (Drucker, 1985). From the structural point of view, four types of innovations have been identified, which are reflected in every organization (OECD/Eurostat, 2018).

They are:

- product innovation, visible changes in product and service capabilities. Such changes encourage the launch of new services or products, or their visible improvement, and thus differentiation from existing products.

- process innovations, in this case are important changes in the methods of creating and delivering products or services

- organizational innovations, are aimed at creating a more effective organizational structure and communication, including changes in workplace organization or in external business relationship roles, accountable 
- marketing innovation is presented by introducing new marketing approaches that can include product design changes, packaging, promotion and placement forms as well as changes in pricing and service delivery methods.

The introduction of innovation in organizations is contingent on two possible approaches, reactive or proactive.

The first approach, i.e. reactive, applies when an organization needs to respond to competitor activities. That is, they must keep up with product or service offerings. To eliminate possible risks of failure, but the economic benefits of such a strategy are limited (Zelenay et al., 2018).

The second approach, proactive to bring new products and services to market with measurable benefits, to attract customers and competitive advantage over other providers A proactive strategy requires a creative and creative team of workers.

From the point of view of scale, we divide innovation into the following five levels:

- simple implementation of the technical system, replacing the old tool by new one,

- innovation that addresses technical discrepancy. In this case, the knowledge of the different fields of industry and knowledge relevant to the desired area is needed,

- innovation containing physical contradiction, knowledge of other industries is required

- new technology is developed containing a breakthrough solution that demands knowledge from different areas of science. This level of innovation also improves technical systems without addressing existing technical issues. Thus, it solves the existing problem by replacing the original technology with a new one,

- the discovery of a new phenomenon, natural, technical, economic and other phenomena.

\section{Business process management and innovation}

Organizations of various types, commercial or non-commercial, are introducing and maintaining BPM - Business Process Management to maintain competitive advantage on the market. A business process is a precisely defined sequence of events or tasks that need to be performed to create a product or service. BPM is a business process management discipline in which process owners, or individual activity owners, model, analyse, measure, improve, optimize and automate (Balco and Drahosova, 2017).

Management focuses on improving the performance of organizations by using a variety of methods. Every business process has its birth certificate, the reason for its existence and its life cycle, which consists of five following activities, design, modelling, execution, monitoring, and optimization. Figure 1 shows the business process life cycle model.

Design and implementation of any business process is preceded by planning and linking with the organization's corporate strategy. The aim of this activity is to review the business process and align it with the services provided, product creation, i.e. the business goals of the organization. It is therefore necessary: 
Figure 1

Lifecycle Business Process Management

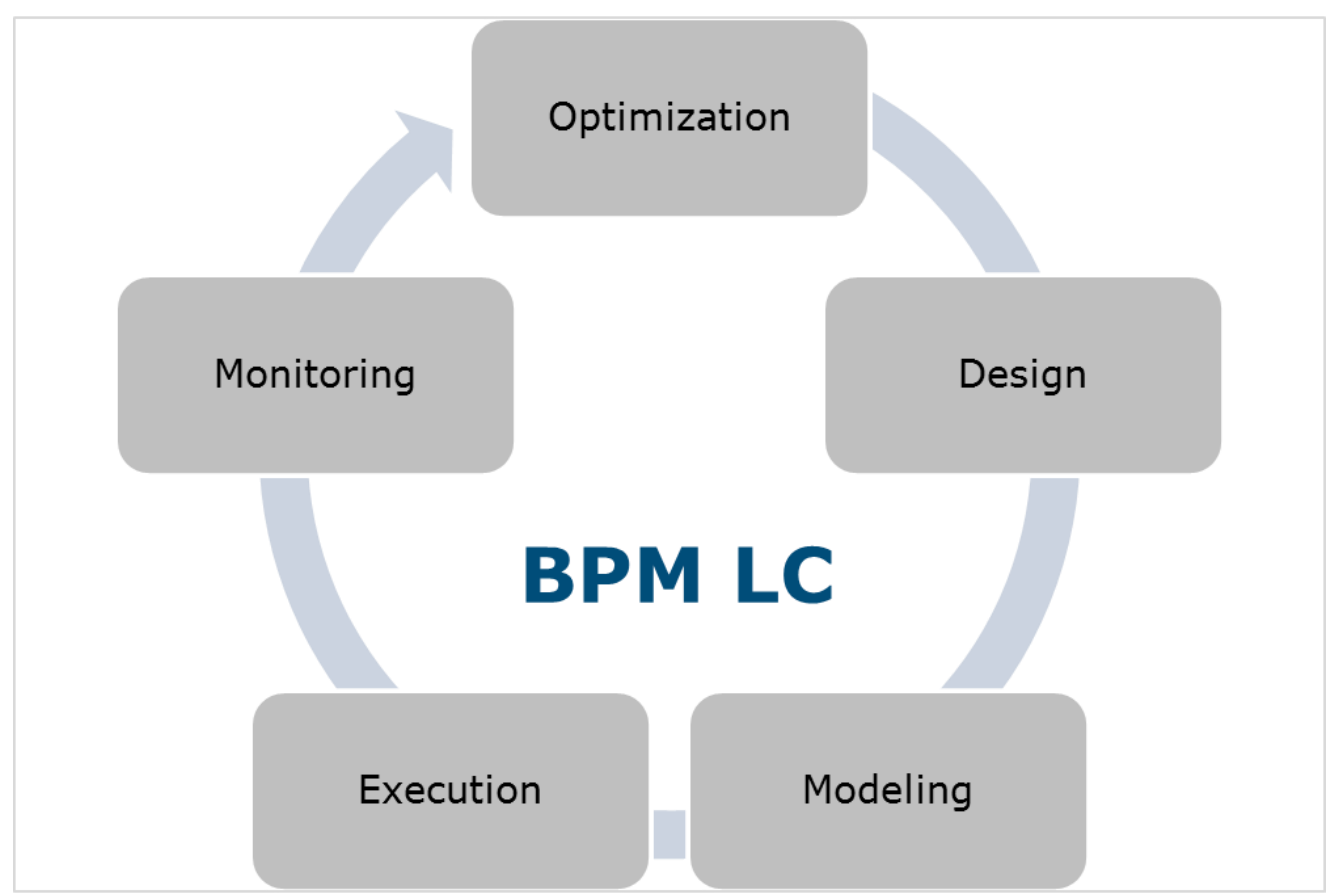

Source: Authors' work

- to clearly understand the organization's profile

- to identify critical and supportive processes have been identified

- to describe planned, realistic KPIs

On the other hand, if the process does not reflect current needs and its optimization is impossible, we are going to change it, that is, we apply reengineering. It is a situation where the process becomes too complex or inefficient and the optimization does not produce the desired output. In practice, this means that the entire process cycle needs to be reorganized to achieve greater efficiency, desired savings or productivity (Balco and Greguš, 2015; Garg, Vecchiola and Buyya, 2013).

\section{Process of automation and artificial intelligence}

By practice is proven, the introduction of automation in the areas of production or service can be the way to increase the efficiency of management and productivity of individual processes. In this case we are replacing the service provider, responding to the suggestion by the slot machine. The idea of introducing a predefined response to a clear stimulus is not new. This approach has been long in the history, where such approaches have already been implemented in mechanical devices.

The automation presents a degree of development characterized by the implementation of manufacturing, management and other processes with minimal impact of human intervention. These technological changes are associated with the existence of automatic production lines and the introduction of automated plants and plants that utilize elements of modern computing and control technology. Automation does not completely exclude human participation. Its role is important in controlling, managing the work of individual technology units (Kvasnička et al., 2010).

The modern IT environments is presented with an intelligent tool that allows you to automate service management and replace manual events used to manage events. Process automation keeps repetitive and manual activities that are a source of error, 
limiting employee development and leading to frustration. In such a situation, we need to think about how to deal with different types of events, requests, complaints or changes in the long term, and how to replace manual work with reasonable automation, which allows operational teams to respond promptly to events (Garg, Versteeg and Buyya, 2011; Garg, Vecchiola and Buyya, 2013).

Removing man's influence in decision-making in automation and increasing the autonomy of technological units is realized through artificial intelligence. Artificial intelligence covers several theories aimed at imitating human schemes or, in general, the biological behaviour of evaluating and analysing environmental stimuli or creativity. Artificial intelligence sets goals, that is, the level of intelligence of the autonomous system, the expectations and seeks solutions available in various disciplines (Balco and Drahosova, 2017).

Artificial intelligence can be used for the following reasons:

- artificial intelligence can be offered as a cloud service, making it available continuously,

- decreasing costs,

- the degree of application and continuous advancement of intelligent algorithms that can learn.

To correctly assess the possibilities of applying artificial intelligence and the potential for the economy, it is important to understand its feasibility.

Autonomous services systems present complicated solutions integrating a wide range of configuration items, communicating bidirectionally integrated into many business processes. These processes include the perception and interpretation of the environment, as well as the transformation of these stimuli into concrete actions. Artificial intelligence technologies are progressing steadily despite the existing setbacks, but it can be said that this is a major challenge that cannot be ignored.

\section{Case study - automation routines and economic impacts}

Practice shows that even a small increase in efficiency can drastically reduce labour, costs and release budgets for other strategic opportunities. We carry out many activities within individual processes manually without automation, resulting in their inefficiency and low productivity.

In this part of an article, we will present the impacts of implementing automation on efficient process management in education.

Universities, education environment are complicated economic-social ecosystem where many events take place in parallel and in two-way mode. It is a provider of a wide range of services that are tracked and used by the users. In classic mode, we use face to face between providers and users, between teacher and students or administration services provided by universities and students. You tested how much time and resources we are losing ineffectively if we are providing these services without intelligent tools. Tool from our point of view are IT tolls and services to increase quality and speed of delivered services. 
Figure 2

Model Push/Pull Services Delivery

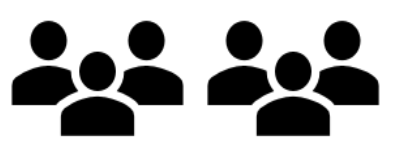

Students

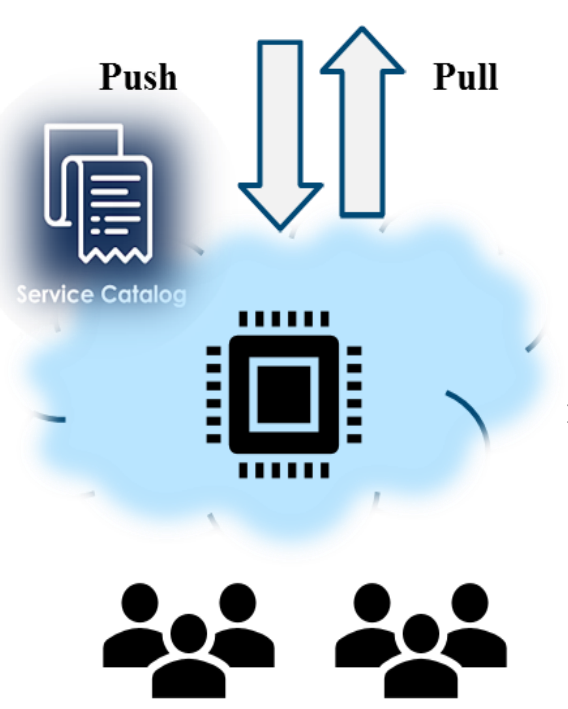

Proactive management

with automation /

reactive service management

Service providers, universities

Source: Balco and Studeničova, 2019

Imagine an ideal situation, where request for knowledge and information's is presented. The proactive management provide to customer automatic information and notifications too. In this way, most of the agenda that involves repetitive activities can be addressed - from requests, through confirmations to various other services. Practice shows that even a small increase in efficiency through process change can significantly reduce labour and costs.

In the Table no. 1, we summarized the effects of the model - Pull service delivery to customers, students. As we can see, in the case of a reactive delivery service, there is a natural phenomenon that service consumers are aware of the status of services through existing communication channels where unnecessary efforts are seen on both sides. 


\section{Table 1}

The Pull Service Delivery Model

\begin{tabular}{|c|c|c|c|}
\hline \multicolumn{4}{|c|}{$\begin{array}{c}\text { Our pilot represents group of } 125 \text { students, where all are using services, it means: The type } \\
\text { of service represents "reactive" approach. }\end{array}$} \\
\hline Type of services & $\begin{array}{c}\text { Type of } \\
\text { communication } \\
\text { channel }\end{array}$ & $\begin{array}{l}\text { Time consumption } \\
\text { per service and } \\
\text { request by } \\
\text { customer-student } \\
\text { in "t-Time" }\end{array}$ & $\begin{array}{l}\text { Time consumption } \\
\text { per service and } \\
\text { request by service } \\
\text { provider - university } \\
\text { in " } \dagger \text {-Time " }\end{array}$ \\
\hline $\begin{array}{c}\text { Request for } \\
\text { information } \\
\text { (include } \\
\text { administration as } \\
\text { well as education } \\
\text { service) }\end{array}$ & $\begin{array}{c}\text { Call centre request } \\
\text { E mail request } \\
\text { SMS request } \\
\text { WEB browsing } \\
\text { Paper sheet } \\
\text { Ticket tool }\end{array}$ & $\begin{array}{l}<7 \dagger \\
<2 \dagger \\
<5 \dagger \\
<40 \dagger \\
<2 \dagger\end{array}$ & $\begin{array}{l}<4 \dagger \\
<2 \dagger \\
N A \\
<20 \dagger \\
<3 \dagger\end{array}$ \\
\hline Complaint & $\begin{array}{c}\text { Call centre request } \\
\text { E mail request } \\
\text { Paper sheet } \\
\text { Ticket tool }\end{array}$ & $\begin{array}{l}<5 \dagger \\
<7 \dagger \\
<30 \dagger \\
<2 \dagger\end{array}$ & $\begin{array}{l}<5 \dagger \\
<4 \dagger \\
<20 \dagger \\
<2 \dagger\end{array}$ \\
\hline Request for change & $\begin{array}{c}\text { Call centre request } \\
\text { E mail request } \\
\text { Paper sheet } \\
\text { Ticket tool }\end{array}$ & $\begin{array}{l}<10 \dagger \\
<7 \dagger \\
<30 t \\
<2 \dagger\end{array}$ & $\begin{aligned} & N A \\
< & 30 \dagger \\
< & 60 t \\
< & 30 \dagger\end{aligned}$ \\
\hline
\end{tabular}

Source: Authors' work

Table 2

The Push Service Delivery Model

\begin{tabular}{|c|c|c|c|}
\hline \multicolumn{4}{|c|}{$\begin{array}{c}\text { Our pilot represents group of } 125 \text { students, where all are using services, it means: The type } \\
\text { of service represents "proactive" approach. }\end{array}$} \\
\hline Type of services & $\begin{array}{c}\text { Type of } \\
\text { communication } \\
\text { channel }\end{array}$ & $\begin{array}{l}\text { Time consumption } \\
\text { per service and } \\
\text { request by } \\
\text { customer-student } \\
\text { in "t-Time" }\end{array}$ & $\begin{array}{l}\text { Time consumption } \\
\text { per service and } \\
\text { request by service } \\
\text { provider - university } \\
\text { in " }+ \text {-Time " }\end{array}$ \\
\hline $\begin{array}{l}\text { Request for } \\
\text { information } \\
\text { (include } \\
\text { administration as } \\
\text { well as education } \\
\text { service) }\end{array}$ & $\begin{array}{c}\text { Call centre request } \\
\text { E mail request } \\
\text { SMS request } \\
\text { WEB browsing } \\
\text { Paper sheet } \\
\text { Ticket tool }\end{array}$ & $\begin{array}{l}<1 \dagger \\
<7 \dagger \\
<2 \dagger \\
<5 \dagger \\
<40 \dagger \\
<2 \dagger\end{array}$ & $\begin{array}{l}<1 \dagger \\
<1 \dagger \\
\text { NA } \\
<20 \dagger \\
<1 \dagger\end{array}$ \\
\hline Complaint & $\begin{array}{c}\text { Call centre request } \\
\text { E mail request } \\
\text { Paper sheet } \\
\text { Ticket tool }\end{array}$ & $\begin{array}{l}<2 \dagger \\
<7 \dagger \\
<30 \dagger \\
<2 \dagger\end{array}$ & $\begin{array}{l}<5 \dagger \\
<4 \dagger \\
<20 \dagger \\
<2 \dagger\end{array}$ \\
\hline Request for change & $\begin{array}{c}\text { Call centre request } \\
\text { E mail request } \\
\text { Paper sheet } \\
\text { Ticket tool }\end{array}$ & $\begin{array}{l}<3 \dagger \\
<7 \dagger \\
<30 \dagger \\
<2 \dagger\end{array}$ & $\begin{aligned} & N A \\
< & 13 t \\
< & 60 t \\
< & 10 \dagger\end{aligned}$ \\
\hline
\end{tabular}

Source: Authors' work 
Savings are presented in our case by time, which can be transformed into financial savings. The time saving is presented by the "t" parameter multiplied by the corresponding measured coefficient. In the case of deployment of automation on the customer side, we observe time savings from $20 \%$ to $60 \%$. In the case of service suppliers, the time savings were higher, it means from $30 \%$ to $90 \%$. The amount of savings depends on the type of service as well as the ability of customers to communicate with smart solutions.

\section{Conclusion}

The implementation of automation as well as the intelligent services based on the artificial intelligence has visible influence the quality of delivered services. Our tests, which we conducted as part of a pilot on several services, shows saving the financial and FTE resources. These results are closely related to modification of business processes and implementation of IT tools in critical points. It cannot be confirmed that each automation generates savings, so it is necessary to apply an individual approach. We have found that many event responses can be realized immediately without waiting, as they have a high degree of uniformity and many users, including a rapid return on investment (ROI) (Balco and Greguš, 2014). The university environment is typical space where new IT tools and services can improve processes of education, speedup communication on the different levels. From the platform's point of view, we recommend going through the cloud services path, as these provide potential customers with pre-defined solutions that can be deployed and used in a few weeks without designing workflows and programming (Zelenay, Balco and Greguš, 2019; GregušKryvinska, 2015). The team's intention is to continue the project on a wider range of services and processes as well as to measure and optimize their connection to the local smart infrastructure.

\section{References}

1. Balco, P., Drahosova, M. (2017), "The economic aspects of the electronization in Education process", in the Proceedings of the 15th International Conference on Emerging eLearning Technologies and Applications (ICETA), Stary Smokovec, Slovakia, IEEE, pp. 1-6.

2. Balco, P., Greguš, M. (2014), "The implementation of innovative services in education by using cloud infrastructure and their economic aspects", Global Journal of Flexible Systems Management, Vol. 15, No. 1, pp. 69-76.

3. Balco, P., Greguš, M. (2015), "Process as a Service (PraaS) for Planning of Resources in Organizations", in the Proceedings of the 2015 International Conference on Intelligent Networking and Collaborative Systems, Taipei, Taiwan, IEEE, pp. 70-73.

4. Balco, P., Studeničova, A. (2019), "Impact of Automation to Event Management efficiency", in the Proceedings of the 11 th International Conference on Intelligent Networking and Collaborative Systems (INCOS), Oita, Japan, Springer, pp. 278-288.

5. Drucker, P. (1985), Innovation and entrepreneurship: principles and practices, HarperTrade, New York.

6. Garg, S. K., Vecchiola, C., Buyya, R. (2013), "Mandi: a market exchange for trading utility and cloud computing services", Journal of Supercomputing, Vol. 64, No. 3, pp. 1153-1174.

7. Garg, S. K., Versteeg, S., Buyya, R. (2011), "SMICloud: Aframework for Computing and Ranking Cloud Services", in the Proceedings of the Fourth IEEE International Conference on Utility and Cloud Computing, Victoria, NSW, Australia, pp. 210-218.

8. Greguš, M., Kryvinska. N. (2015), Service orientation of enterprises-aspects, dimensions, technologies, 1. Vyd, Bratislava, Univerzita Komenského. 
9. Kvasnička, V., Pospíchal, J., Návrat, P., Lacko, P., Trebatický, P. (2010), Umelá inteligencia a kognitívna veda II, Slovenská technická univerzita v Bratislave.

10. OECD/Eurostat (2018), Oslo Manual 2018: Guidelines for Collecting, Reporting and Using Data on Innovation, The Measurement of Scientific, Technological and Innovation Activities, 4th Edition, OECD Publishing, Paris/Eurostat, Luxembourg.

11. Zelenay, J., Balco, P., Greguš, M. (2019), "Cloud technologies - solution for secure communication and collaboration", in the Proceedings of the 10th International Conference on Ambient Systems, Networks and Technologies (ANT), Leuven, Belgium, Elsevier, pp. 567-574.

12. Zelenay, J., Balco, P., Greguš, M., Luha, J. (2018), "Solutions for Secure Collaboration, Selection of Methodology, Implementation and Case Studies for Their Use", in the Proceedings of the 10th International Conference on Intelligent Networking and Collaborative Systems, Bratislava, Slovakia, Springer, pp. 24-33.

\section{About the authors}

Peter Balco, he studied Radio-electronics and Telemetry Systems at the Faculty of Electrical Engineering and Informatics of the Technical University in Kosice, Slovakia. DEA Diploma and Ph.D. defended at C.E.M.-CNRS Montpellier, USTL II, France for optoelectronics and optoelectronic systems. He holds a Professional Diploma in MBA Level 1 Business School CUB, a member of The Open University UK. He has many years of experience in managing IT and TELCO operating environments as well as IT and TELCO projects for large international organizations. He is currently working on the position of Solution Design Architect for Atos IT Solutions and Services in Slovakia. He is a member of Technical Committee TK 37 (Information Technology) in Slovak Institute of Technical Standardization. He is a certified auditor for ISO9000, ISO20000, and ISO27000 holders of PRINCE2 and P3O certificates. The author can be contacted at peter.balco@fm.uniba.sk.

Martina Drahošová, is a project manager on the national project The Increase in Innovation Performance of the Slovak Economy, Department of communication and events at the Slovak Innovation and Energy Agency. As well, she is a researcher at Faculty of Management, Comenius University in Bratislava. She received PhD in management at the Faculty of Management, Comenius University in Bratislava, Slovakia. Her main research interests are innovation, marketing, social media and project management. She published several scientific papers in international and national journals and participated in many scientific international conferences. The author can be contacted at martina.drahosova@siea.gov.sk.

Michal Greguš, Jr., is working as a lecturer at the Faculty of Management, Comenius University in Bratislava. His main interest is in IT and database systems. After graduation in mathematics he worked five years in the IT industry in a private company Centaur Ltd. on several interesting projects for small and medium enterprises and for large companies. He worked on projects of databases, web technologies and programming in higher level languages. Now he is doing research projects in big data management. The author can be contacted at michal.gregusml@fm.uniba.sk. 